\title{
Effects of physical gradients on the production dynamics of sediment-associated algae
}

\author{
Michael W. Davis ${ }^{1}$ and C. David McIntire ${ }^{2}$ \\ ${ }^{1}$ Harbor Branch Foundation, Inc., RR 1, Box 196, Ft. Pierce, Florida 33450, USA \\ ${ }^{2}$ Department of Botany and Plant Pathology, Oregon State University, Corvallis, Oregon 97331, USA
}

\begin{abstract}
Sediment-associated microalgal biomass expressed as chlorophyll a concentration, total organic matter concentration expressed as ash-free dry weight, and hourly rates of net community primary production and community oxygen consumption were measured at monthly intervals at medium sand, fine sand, and silt sites between 0.5 and $2.0 \mathrm{~m}$ above MLLW during an entire year at Netarts Bay, Oregon, USA. Estimated mean annual rates of net primary production were $38 \mathrm{~g} \mathrm{C} \mathrm{m}^{-2}$ in sand, $53 \mathrm{~g} \mathrm{C} \mathrm{m}^{-2}$ in fine sand, and $21 \mathrm{~g} \mathrm{C} \mathrm{m}^{-2}$ in silt. We tested the hypotheses that benthic algal primary production dynamics were controlled by sediment type, tidal height, and season. Our results show that although there is a relationship between these physical factors and benthic algal production dymamics, this relationship is neither as simple nor as linear as had been previously suggested in published studies. Future research on benthic algae should consider the effects of biotic and chemical factors in greater detail then has previously been attempted.
\end{abstract}

\section{INTRODUCTION}

The mechanisms which control the dynamics of benthic autotrophy in estuaries have not been examined in sufficient detail to bring about a clear understanding of the process. Previous studies of estuarine primary production have indicated that such factors as light intensity, day length, temperature, water movements and tidal cycle, sediment moisture and stability, animal activity, and nutrient supply can affect production dynamics of sediment-associated algae (Pamatmat, 1968; Cadée and Hegeman, 1974; Admiraal and Peletier, 1980). However, the interactions between these factors and the structural and functional attributes of benthic algal assemblages are complex and virtually unexplored by field and laboratory research. Published studies of benthic autotrophy in Oregon estuaries report the results of laboratory measurements of primary production for dispersed sediment (Riznyk and Phinney, 1972), for microalgal assemblages on plastic substrates (McIntire and Wulff, 1969; Wulff and McIntire, 1972), and for isolated species of macroalgae (Kjeldsen and Phinney, 1971). The distribution of sediment-associated diatoms in an
Oregon estuary was investigated by Amspoker and McIntire (1978).

The purpose of the research reported here was to test hypotheses concerning some factors which control the distribution and primary production of benthic algae in estuaries. We hypothesized that benthic algae were controlled by seasonal changes of light and temperature, and by sediment type and intertidal height. These hypotheses were tested by sampling benthic algal biomass, primary production, and associated physical factors in an unpolluted estuary, Netarts Bay, Oregon. In this estuary, sampling sites were available which represented a distinct gradient of sediment type ranging from medium sand to coarse silt, separated from the obvious gradient of intertidal exposure. Experiments were also conducted in the laboratory using intact cores of sediment and isolated epipelic diatoms to investigate the effects of light intensity and temperature on benthic algal primary production. Because this research examined autotrophic and heterotrophic processes which occur in many estuaries, the understanding of these processes in Netarts Bay is relevant to problems that extend beyond the geographical limits of this particular ecosystem. 


\section{MATERLALS AND METHODS}

\section{Study site}

Netarts Bay $\left(45^{\circ} 25^{\prime} \mathrm{N} ; 123^{\circ} 56^{\prime} \mathrm{W}\right)$ is the sixth largest estuary in Oregon with a surface area of 941 ha, of which 612 ha are classified as tideland area (Fig. 1). The permanently submerged land is only 329 ha in

\section{NETARTS BAY, OREGON}

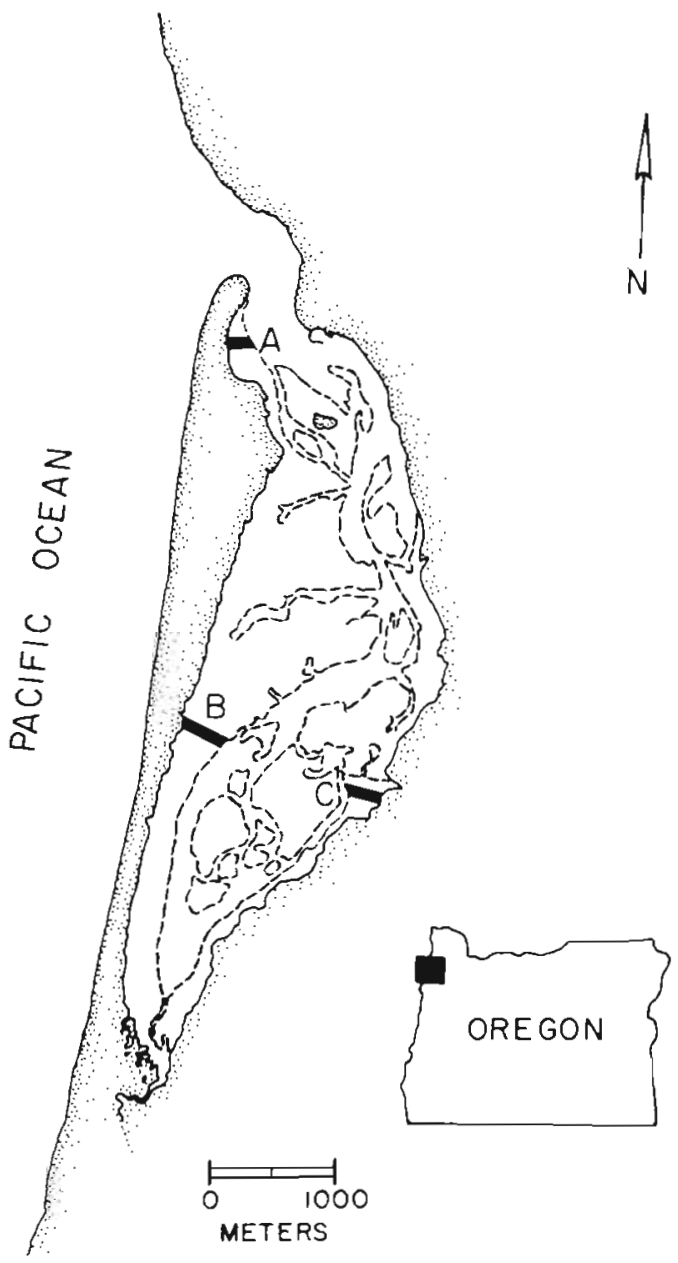

Fig. 1. Map of Netarts Bay, Oregon, showing study sites. Site A: SAND site; Site B: FINE SAND site; Site C: SILT site. Dotted line: MLLW

area, and is restricted to a narrow channel extending from the mouth of the estuary to the mudflat at the south end. Netarts Bay drains a water-shed of only $36.3 \mathrm{~km}^{2}$ and is partially exposed to waves at the mouth. The depression which the estuary now occupies was formed as a consequence of the differential erosion of the soft sedimentary rock between the basaltic headlands of Cape Meares and Cape Lookout during the Late Tertiary Period. The sand spit which separates the bay from the Pacific Ocean is a remnant of 3 sand dunes which have eroded as a consequence of sea level elevation after the last period of glaciation. Because of the lack of any major tributaries, the estuary exhibits a relatively high salinity with values usually above $30 \% \mathrm{~S}$ and seldom below $14 \% \mathrm{~S}$ at any location. Recent dye studies by the US Environmental Protection Agency (unpubl., 1978) indicated that horizontal mixing is complex, with only limited mixing occurring between ocean water and bay water during each tidal cycle. Netarts Bay is exposed to mixed semidiurnal tides with a maximum tidal range of $3 \mathrm{~m}$. Sediments introduced into the bay average about 2,250 tons annually. Benthic autotrophy and heterotrophy were investigated at three study sites in Netarts Bay: The SAND site, the FINE SAND site, and the SILT site (Fig. 1). These sites were representative of a large proportion of the total intertidal area of the estuary. The SAND site was near the mouth of the bay and characterized by medium sand. The FINE SAND site was located on the western shore of the bay and had sediments primarily composed of fine sand. A third site, the SILT site, was established on the eastern shore of the bay and sediments at this site were primarily coarse silt.

All sites were exposed to moderate wave action. Diatoms were abundant on and in the sediments at all sites, while blue-green algae occurred at the mean high water level at the FINE SAND site and SILT site. Macroalgae (Enteromorpha ssp.) were abundant at the SAND and FINE SAND sites in the summer, but were absent at the SILT site throughout the year.

\section{Sampling}

The sampling strategy at each study site involved the collection of sediment cores for the measurement of chlorophyll a concentration, the concentration of organic matter, and rates of community oxygen production and community oxygen uptake. At each site, $50 \mathrm{~m}$ horizontal transects were established at $0.5,1.0$, 1.5 , and $2.0 \mathrm{~m}$ above mean lower low water (MLLW). Sediment cores were obtained monthly along each transect, 3 for measurements of primary production and oxygen uptake, 6 for analysis of chlorophyll a concentration, and 3 for the analysis of organic matter concentration. Measurement of chlorophyll $a$ and organic matter concentrations was made for the top $\mathrm{cm}$ of sediment. Cores for the measurement of primary production were incubated in situ in field respirometers and subsampled after incubation for the measurement of chlorophyll a concentration in the top $\mathrm{cm}$ of sediment. The location of the samples along each transect was determined from a table of random num- 
bers. Sampling was initiated in March 1980 and continued for a period ending in March 1981.

Monthly measurements of selected physical variables also were made at the transects of all 3 study sites. These variables included temperature, salinity, light intensity, and changes in sediment height. Sediment samples also were obtained bimonthly for the analysis of grain size.

\section{Primary production}

Net community oxygen production and community oxygen uptake were estimated in the field from measurements of dissolved oxygen in stirred, light and dark Plexiglas chambers designed to hold intact cores of sediment. The details of chamber design were described by Davis (1981). Between May and September 1980, measurements were made in 5.71 chambers which enclosed a sediment surface area of $128.6 \mathrm{~cm}^{2}$. Estimates of oxygen evolution and uptake were based on in situ measurements for periods ranging from 4.0 to $7.5 \mathrm{~h}$ between initial and final readings. High tide occurred between 11:00 and 13:00 during the incubations. Initially, time course experiments were performed which showed that changes of oxygen in the chambers were linear over an $8 \mathrm{~h}$ period in the field. Between October 1980 and March 1981, primary production and oxygen uptake were measured in $300 \mathrm{ml}$ chambers which enclosed a sediment surface area of $36.3 \mathrm{~cm}^{2}$. With these chambers, measurement periods varied from 0.5 to $1.0 \mathrm{~h}$ between initial and final readings. Incubations were conducted between 10:00 and 15:00. All measurements of dissolved oxygen were made polarigraphically with an Orbisphere ${ }^{\circledR}$ salinity-corrected oxygen system. Temperature in both types of chambers and between light and dark chambers did not change more than $1.5 \mathbf{C}^{\circ}$ over entire incubation periods. Time course experiments with sediment cores in both types of chambers indicated that chamber type had no significant effect on the final calculated rates of primary production or oxygen uptake throughout an eight hour time period. The light and dark bottle method was used to correct all measurements for the effect of plankton metabolism (Strickland and Parsons, 1972). During the study in Netarts Bay, plankton metabolism was negligible except in August 1980.

Hourly rates of gross primary production of benthic algae were calculated by adding the community oxygen uptake in the dark to the net community oxygen production in the light for an equivalent period of time. Rates of gross primary production expressed as $m g \mathrm{O}_{2} \mathrm{~m}^{-7} \mathrm{~h}^{-1}$ were converted to $\mathrm{mg}$ carbon $\mathrm{m}^{-2} \mathrm{~h}^{-1}$ while assuming a photosynthetic quotient of 1.2, i.e.
$\mathrm{mgC}=0.312 \times \mathrm{mg} \mathrm{O}_{2}$ (Ryther, 1956). Rates of oxygen uptake were converted to carbon equivalents while assuming a respiratory quotient of 1.0 , i.e. $\mathrm{mg} \mathrm{C}=0.375 \times \mathrm{mg} \mathrm{O}_{2}$ (Westlake, 1965). Daily rates of community oxygen consumption were calculated assuming a constant hourly rate times $24 \mathrm{~h}$. Daily rates of gross primary production (DGPP) were calculated assuming a constant hourly rate of photosynthesis: DGPP $=\mathrm{mg} \mathrm{O}_{2} \mathrm{~m}^{-2} \mathrm{~h}^{-1} \times$ photosynthetic day length, where photosynthetic day length ranged from $6.0 \mathrm{~h}$ in December to $12.2 \mathrm{~h}$ in June. Calculation of annual rates of primary production and community oxygen uptake were made by summing daily rates over an annual period.

\section{Biomass}

Microalgal biomass was expressed as concentration of chlorophyll $a$ in the sediment. Samples of sediment were collected with a $12 \mathrm{~cm}$ long plastic corer (internal diameter of $2.3 \mathrm{~cm}$ ). The cores were frozen, and sections from the top $\mathrm{cm}$ were excised with a knife. Extractions were performed according to the method of Strickland and Parsons (1972), and the Lorenzen equation, which corrected for phaeopigments, was used to calculate the concentration of chlorophyll a.

Sediment was sampled for organic matter content using the same coring device that was used for the chlorophyll samples. In this case, core sections were dried at $70^{\circ} \mathrm{C}$ for $48 \mathrm{~h}$, weighed, and then ashed at $450^{\circ} \mathrm{C}$ in a muffle furnace for $24 \mathrm{~h}$ and reweighed. To correct for the loss of sediment water of hydration, ashed sediment was redried at $90^{\circ} \mathrm{C}$ for $24 \mathrm{~h}$ after an addition of distilled water and reweighed.

\section{Physical and chemical variables}

Selected physical and chemical variables were monitored concurrently with measurements of primary production and biomass. Bimonthly samples of the top $\mathrm{cm}$ of sediment were taken for the estimation of grain size and related variables (Buchanan and Kain, 1971). Light intensity was measured in $\mu \mathrm{E} \mathrm{m}^{-2} \mathrm{~s}^{-1}$ photosynthetically active radiation with a Licor ${ }^{\beta}$ quantum meter. Light transmission through the sediment was determined by the method of Haardt and Nielsen (1980). Bimetal or thermistor probes were used to measure temperature. Salinity was measured with a temperature-compensated AO Goldberg ${ }^{(\sqrt{3}}$ refractometer. Samples for the analysis of nitrite-nitrate $\left(\mathrm{NO}_{2}-\mathrm{NO}_{3}\right)$, ammonium $\left(\mathrm{NH}_{4}\right)$, orthophosphate $\left(\mathrm{PO}_{4}\right)$ and molybdate-reactive silica $\left(\mathrm{SiO}_{3}\right)$ were taken July, August, and September from water in the respirometer cham- 
bers before and after incubation. These samples were analyzed by methods for autoanalysis of nutrients (Strickland and Parsons, 1972).

\section{Laboratory experimental procedures}

Laboratory experiments were designed to examine the effects of light intensity and temperature on rates of benthic primary production and oxygen uptake. Moreover, the laboratory work provided estimates of the ratio of chlorophyll a concentration to microalgal biomass and the ratio of net primary production to gross primary production in isolated assemblages of epipelic diatoms. These ratios provided a basis for the generation of energy budgets for the study sites in Netarts Bay.

For the experimental work, samples of sediment and intact sediment cores were collected from a tidal fiat in Yaquina Bay, Oregon, near the Oregon State University Marine Science Center. Autotrophic assemblages at this site were similar in species composition and biomass to the assemblages under investigation at Netarts Bay. Intact sediment cores with microalgae were transferred to $300 \mathrm{ml}$ Plexiglas chambers; and measurements of primary production, oxygen uptake and biomass were made at different light intensities and temperatures using the same methods described above for the field work. Incubations were performed under sunlight or a light fixture with cool-white flourescent and incandescent lamps, and fiberglass screen was used as a neutral density filter to control light intensity.

Motile, epipelic diatom assemblages were isolated from sediment samples in sand-filtered, UV-treated seawater by the method described by Jonge (1980). Diatoms migrated out of their associated sediment, up through clean quartz sand and into lens tissue. This tissue was taken up and rinsed with filtered $(0.45 \mu \mathrm{m})$ seawater which was then filtered $(50 \mu \mathrm{m})$ to remove animals and sand grains. The resulting epipelic diatom suspensions were used to establish relationships between primary production and chlorophyll a concentration, between concentrations of organic matter and chlorophyll $a$, and for measurements of diatom respiration. Measurements of photosynthesis and respiration by the diatom suspensions were made in stirred $50 \mathrm{ml}$ test tubes using the light and dark bottle oxygen method (Strickland and Parsons, 1972). The diatom suspensions were incubated for 0.5 to $1.0 \mathrm{~h}$ in the dark or at a light intensity of $210 \mu \mathrm{E} \mathrm{m}^{-2} \mathrm{~s}^{-1}$, and at a temperature of $14{ }^{\circ} \mathrm{C}$ and a salinity of 30 to $33 \% \mathrm{~S}$. The chlorophyll $a$ and organic matter concentrations of the diatom assemblages were determined by the same methods described above for the field work, after sam- ples of the suspensions were collected on pre-ashed glass fiber filters.

Rates of primary production and community oxygen uptake estimated from laboratory systems which were sampled hourly for $8 \mathrm{~h}$ did not show variation associated with the effect of time. These experiments were conducted with intact sediment cores and isolated epipelic diatom assemblages obtained from the field at intervals of 60 to 90 days for a year. Diel rhythms were obvious, and associated with alternating periods of light and dark.

\section{Data analysis}

Biomass and production data from the study sites were analyzed by a three-way analysis of variance with sediment type, tidal height, and time treated as main effects; the three-way interaction mean square was used as the error term in calculating $F$ values. Regression methods also were used for curve fitting and parameter estimation. All statistical analyses were performed with a Control Data Corporation Cyber 70 computer at the Oregon State University Computer Center using the SPSS system (Nie et al., 1975), the REGRESS subsystem of SIPS (Rowe and Brenne, 1981), and NONLIN, a nonlinear curve fitting program. Statistical significance was defined as $\mathrm{P}<.05$.

\section{RESULTS}

\section{Physical properties of the intertidal}

Mean sediment grain size expressed in phi units (Buchanan and Kain, 1971) was $2.28(0.21 \mathrm{~mm})$ at the SAND site, $2.66(0.16 \mathrm{~mm})$ at the FINE SAND site, and $3.79(0.07 \mathrm{~mm})$ at the SILT site. Monthly observations of reference sediment-level markers indicated that there were monthly changes in sediment level which ranged from 0.0 to $3.0 \mathrm{~cm}$, the larger values of which could account for some burial or export of algal biomass. Net change of sediment level during the entire study period was not detected, except at the SAND site at $1.0 \mathrm{~m}$ above MLLW and at the FINE SAND site at 2.0 and $0.5 \mathrm{~m}$ above MLLW. The SILT site exhibited the least change in sediment level during the study period. During tidal exposure of the sediment, drying was reduced by the presence of a film of water ( 2 to $20 \mathrm{~mm}$ ) which remained over large areas of the bay, trapped by animal holes and debris of Zostera marina L. and Enteromorpha prolifera (Mull.) J. Ag. Actual drying of the sediment during exposure occurred at intertidal levels greater than $1.7 \mathrm{~m}$ above MLLW and was limited to the margin of the bay. The presence 
of holes in the sediment surface ( 2 to $30 \mathrm{~mm}$ diameter), especially at the SILT site, reduced the surface area of sediment available for colonization by microalgae.

Incident photosynthetically active radiation (PhAR) ranged from 0.5 to $60 \mathrm{E} \mathrm{m}^{-2} \mathrm{~d}^{-1}$ and was chiefly influenced by day length and cloud cover. Light extinction coefficients calculated from monthly measurements of PhAR in the water column over the study sites at high tide, at noon $\pm 1 \mathrm{~h}$, ranged from 0.40 to 0.87 per $1 \mathrm{~m}$ depth. These values were associated with relatively clear water over the intertidal area. Lower values were observed at the SAND and FINE SAND sites relative to the SILT site. During the days when high tide was at noon $\pm 1 \mathrm{~h}, \mathrm{PhAR}$ was greater than $200 \mu \mathrm{E} \mathrm{m}^{-2} \mathrm{~s}^{-1}$ at the sediment surface at $0.5 \mathrm{~m}$ above MLLW at the SAND and FINE SAND sites from April to September. The SILT site at this intertidal level received more than $100 \mu \mathrm{E} \mathrm{m}^{-2} \mathrm{~s}^{-1}$ during this time period. Between October and March, PhAR sampled at high tide $\pm 1 \mathrm{~h}$ at $0.5 \mathrm{~m}$ above MLLW at all sites was generally below $200 \mu \mathrm{E} \mathrm{m}^{-2} \mathrm{~s}^{-1}$. Reduction of PhAR to $1.0 \%$ of the intensity at the sediment surface was reached at $2.55 \mathrm{~mm}$ below the surface at the SAND site. Corresponding values for FINE SAND and SILT sites were $2.00 \mathrm{~mm}$ and $1.30 \mathrm{~mm}$, respectively.

Other non-biological variables of interest included temperature, salinity and nutrient concentrations. The temperature of the air, water, and exposed sediment at the study sites ranged from 0 to $24{ }^{\circ} \mathrm{C}$, from 8 to $18^{\circ} \mathrm{C}$, and from 2 to $19^{\circ} \mathrm{C}$ during the study, respectively. Salinity in the water column of Netarts Bay ranged from 28 to $34 \%$ S, while values for the interstitial water of the sediments usually varied between 25 and $35 \% \mathrm{~S}$. However, interstitial water at $2.0 \mathrm{~m}$ above MLLW reached values as low as $5 \% \mathrm{~S}$ at all 3 sites during rainstorms or periods of terrestrial runoff from groundwater seepage. Nutrient concentrations in the water from the respirometer chambers were measured before and after periods of incubation in July, August, and September. Mean concentrations of $\mathrm{NH}_{A}$ at the SAND, FINE SAND and SILT sites were 1.48, 1.67, and $1.67 \mu \mathrm{M}$, respectively. Corresponding values for $\mathrm{NO}_{2}-\mathrm{NO}_{3}$ were $2.42,0.21$, and $0.29 \mu \mathrm{M}$; for $\mathrm{PO}_{4}$ were $0.43,0.39$, and $0.39 \mu \mathrm{M}$; and for $\mathrm{SiO}_{3}$ were $13.14,13.36$, and $13.80 \mu \mathrm{M}$, respectively. No significant changes in nutrient concentrations occurred during the incubation periods, except when Enteromorpha prolifera was present in some chambers during July and August.

\section{Biomass}

Microalgal biomass expressed as the concentration of chlorophyll $a$ in the top $\mathrm{cm}$ of sediment varied seasonally (Fig. 2). An analysis of variance indicated that there were significant differences among mean concentratrions associated with the effects of sediment type, tidal height, time, and a two-way interaction between sediment type and tidal height. Mean concentrations of chlorophyll $a$ in the top $\mathrm{cm}$ of sediment for the entire study period were $46.2 \mathrm{mg} \mathrm{m}^{-2}$ (SAND site), $74.7 \mathrm{mg} \mathrm{m}^{-2}$ (FINE SAND site), and $93.7 \mathrm{mg} \mathrm{m}^{-2}$ (SILT site).

The concentration of organic matter in the top $\mathrm{cm}$ of sediment, expressed as ash-free dry weight, changed gradually throughout the study period (Fig. 3). At Mean High Water $(2.0 \mathrm{~m}$ above MLLW), at the FINE SAND and SILT sites, the strand line deposited material from the growth of Zostera and Enteromorpha in the bay during the summer and fall. There were significant differences among mean concentrations associated with the effects of sediment type, tidal height, time, and a two-way interaction between sediment type and tidal height. The SILT site had the highest mean concentration of organic matter during the study period $\left(378 \mathrm{~g} \mathrm{~m}^{-2}\right)$, followed by the FINE SAND site $\left(204 \mathrm{~g} \mathrm{~m}^{-2}\right)$, and the SAND site $\left(134 \mathrm{~g} \mathrm{~m}^{-2}\right)$.

\section{Community primary production and oxygen uptake}

The maximum hourly rate of microalgal production occurred in the summer when Enteromorpha prolifera sporelings were abundant in the sediment (Fig. 4). The only significant differences in the mean hourly rates were associated with the effect of time. When calculated rates from chambers which contained E. prolifera were included, the FINE SAND site had the highest mean hourly rate of gross primary production $47 \mathrm{mg}$ $\mathrm{C} \mathrm{m}^{-2} \mathrm{~h}^{-1}$ ), followed by the SAND site $(37 \mathrm{mg}$ $\mathrm{C} \mathrm{mg}^{-2} \mathrm{~h}^{-1}$ ) and the SILT site (25 $\mathrm{mg} \mathrm{C} \mathrm{m}^{-2} \mathrm{~h}^{-1}$ ). If calculated rates from chambers which contained E. prolifera were excluded, the 3 study sites had similar mean hourly rates of gross primary production; 28 , 28 and $25 \mathrm{mg} \mathrm{C} \mathrm{m}{ }^{-2} \mathrm{~h}^{-1}$ for the SAND, FINE SAND, and SILT sites, respectively.

Because of the difference in growth form, the contribution of mature plants of Enteromorpha prolifera to the total algal primary production at the study sites was estimated in separate measurements. E. prolifera was conspicuous from June to September at the SAND and FINE SAND sites, where the mean biomass during this time was $500 \mathrm{~g}$ dry weight $\mathrm{m}^{-2}$. E. prolifera was absent from the SILT site, except in strand line material as explained above.

The maximum hourly community oxygen uptake by the sediments occurred during the summer when temperatures were relatively high (Fig. 4). There were significant differences among mean hourly rates of oxygen uptake associated with the effects of sediment 


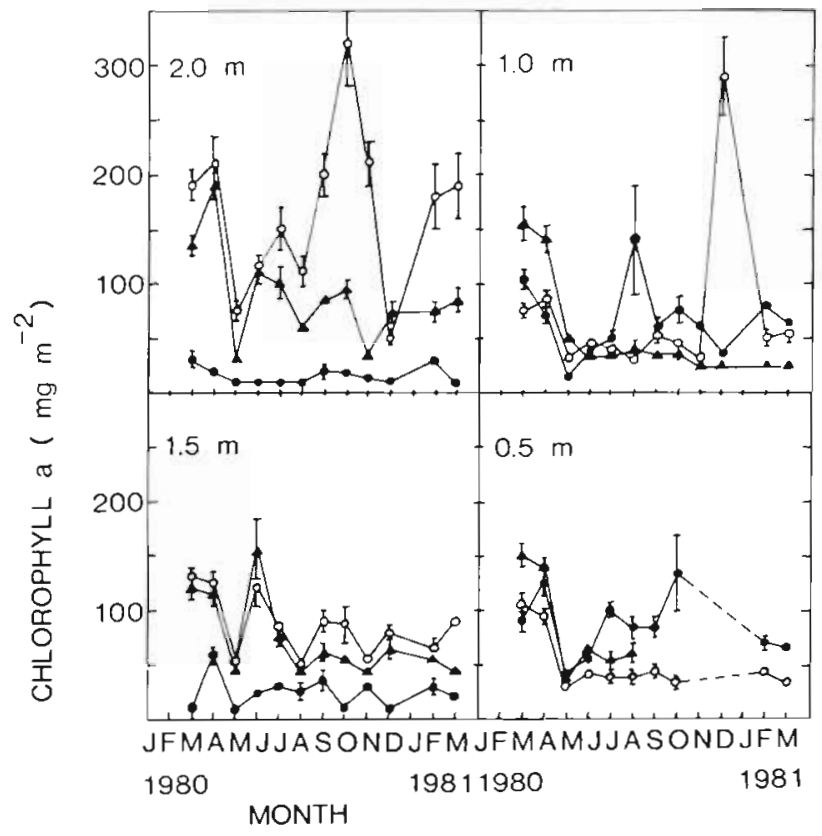

Fig. 2. Concentrations of chlorophyll $a$ at SAND ( $\bullet$ ), FINE SAND (4), and SILT $(O)$ sites at $2.0,1.5,1.0$, and $0.5 \mathrm{~m}$ above MLLW. Means \pm 1 standard error

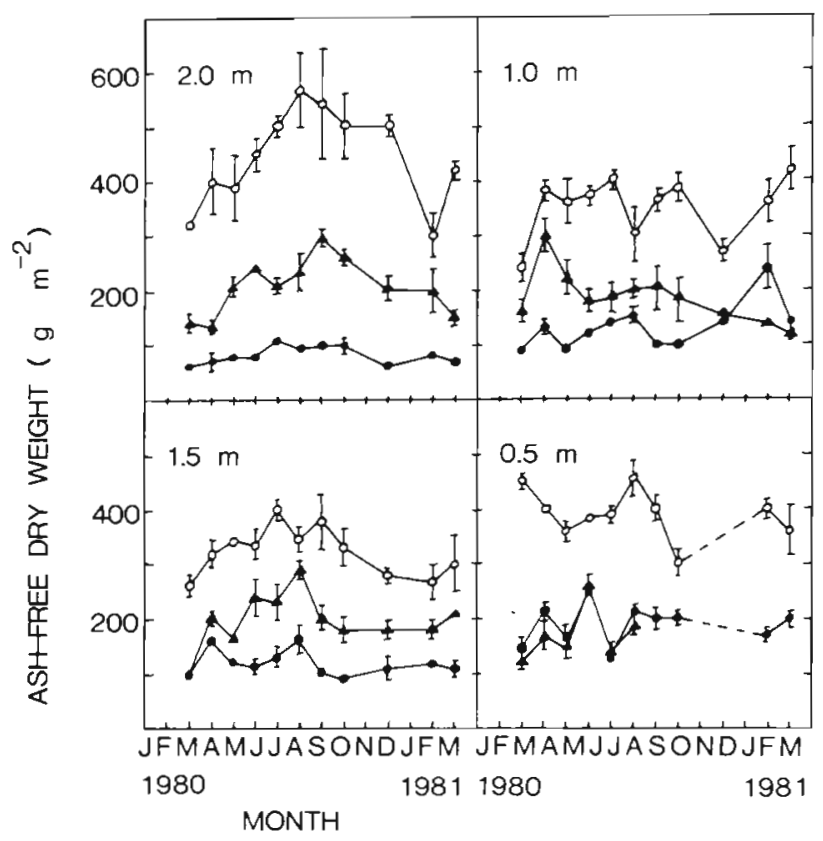

Fig. 3. Concentrations of organic matter expressed as ash-free dry weight at SAND (•), FINE SAND (4), and SILT (O) sites, at $2.0,1.5,1.0$, and $0.5 \mathrm{~m}$ above MLLW. Means \pm 1 standard error

type, time, and a two-way interaction between sediment type and tidal height.

As an index to benthic autotrophy, the ratio of the estimated daily ( $24 \mathrm{~h}$ ) rate of gross primary production to the corresponding estimated daily rate of community oxygen uptake was calculated. We assumed a

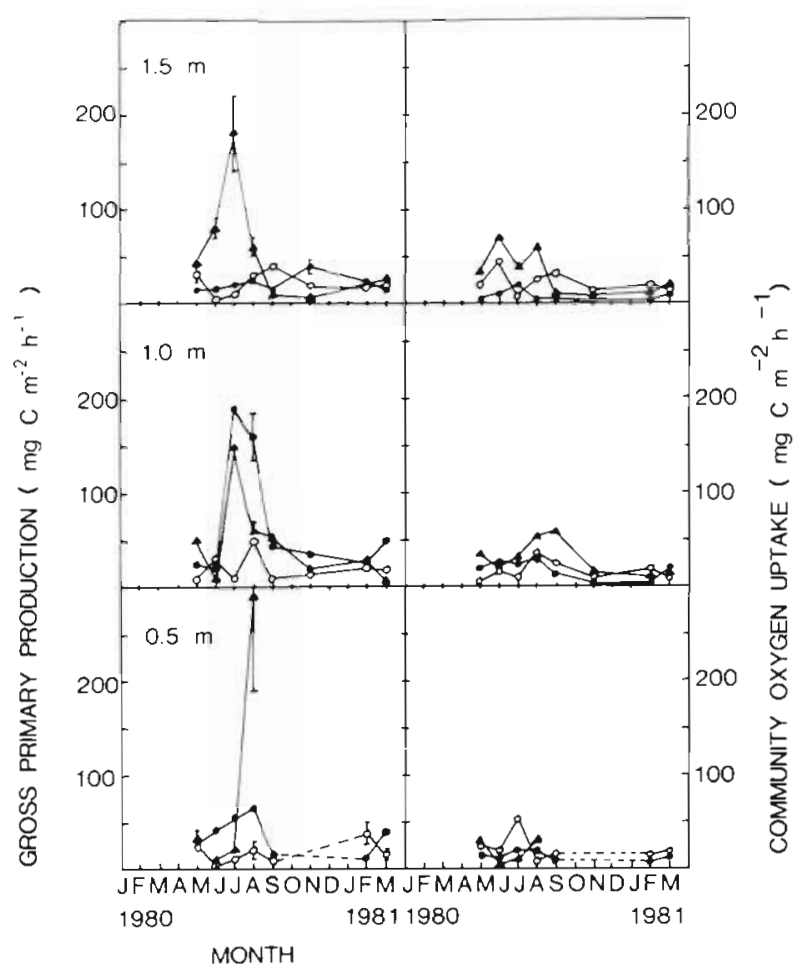

Fig. 4. Rates of gross primary production and community oxygen uptake in carbon equivalents at $\operatorname{SAND}(\bullet)$, FINE SAND ( 4$)$, and SILT $(0)$ sites, at $1.5,1.0$, and $0.5 \mathrm{~m}$ above MLLW. Values for primary production: means \pm 1 standard error, and means for community oxygen uptake

photosynthetic day length ranging from $6 \mathrm{~h}$ in December to $12.2 \mathrm{~h}$ in June. This assumption is based on the measured light intensities at the deepest sampling sites (see above) and a photosynthetic saturation intensity of $200 \mu \mathrm{E} \mathrm{m}^{-2} \mathrm{~s}^{-1}$ (see below). In cases where the light intensity was less than saturation, the measured hourly photosynthetic rates in situ were assumed to reflect the decreases caused by limiting light intensity. Photosynthetic day length was calculated on the basis of the number of hours that light was at least greater than $100 \mu \mathrm{E} \mathrm{m}^{-2} \mathrm{~s}^{-1}$ at the $0.5 \mathrm{~m}$ above MLLW sampling levels. The mean ratios from the SAND, FINE SAND, and SILT sites were $3.19,0.77$, and 0.75 , indicating relatively more heterotrophic activity at the two sites with finer sediment.

\section{Relationship among variables}

In general correlation coefficients $(\mathrm{r})$ for selected pairs of physical and biological variables monitored at Netarts Bay were low. There was a significant correlation between chlorophyll a concentration in the top $\mathrm{cm}$ of sediment in the respirometer cores and the calculated hourly rate of gross primary production $(r=0.63)$. The correlation analysis indicated that the only likely 
predictor of calculated hourly gross primary production was chlorophyll a concentration in the top $\mathrm{cm}$ of sediment. The linear equations corresponding to each study site and to the pooled data from all sites are presented in Table 1. The observed and predicted data for the relationship of gross primary production to chlorophyll a in Netarts Bay are given in Fig. 5. These

Table 1. Linear equations expressing gross primary production (GPP) as a function of the concentration of chlorophyll $a$ (CHLR) in the top $\mathrm{cm}$ of sediment in Netarts Bay. Units for GPP and CHLR are mg C m $\mathrm{m}^{-2} \mathrm{~h}^{-1}$ and $\mathrm{mg} \mathrm{m} \mathrm{m}^{-2}$ respectively. Models correspond to SAND, FINE SAND, and SILT sites in Netarts Bay, and to pooled data for Netarts Bay

\begin{tabular}{|lccc|}
\hline Site & \multicolumn{1}{c}{ Model } & $\mathrm{n}$ & $\mathrm{r}^{2}$ \\
\hline SAND & $\widehat{\mathrm{GPP}}=10.47+0.41 \mathrm{CHLR}$ & 23 & 0.50 \\
FINE SAND & $\widehat{\mathrm{GPP}}=-3.56+0.65 \mathrm{CHLR}$ & 20 & 0.37 \\
SILT & $\widehat{\mathrm{GPP}}=7.60+0.30 \mathrm{CHLR}$ & 26 & 0.55 \\
POOLED DATA & $\widehat{\mathrm{GPP}}=9.57+0.35$ CHLR & 69 & 0.40 \\
\hline
\end{tabular}

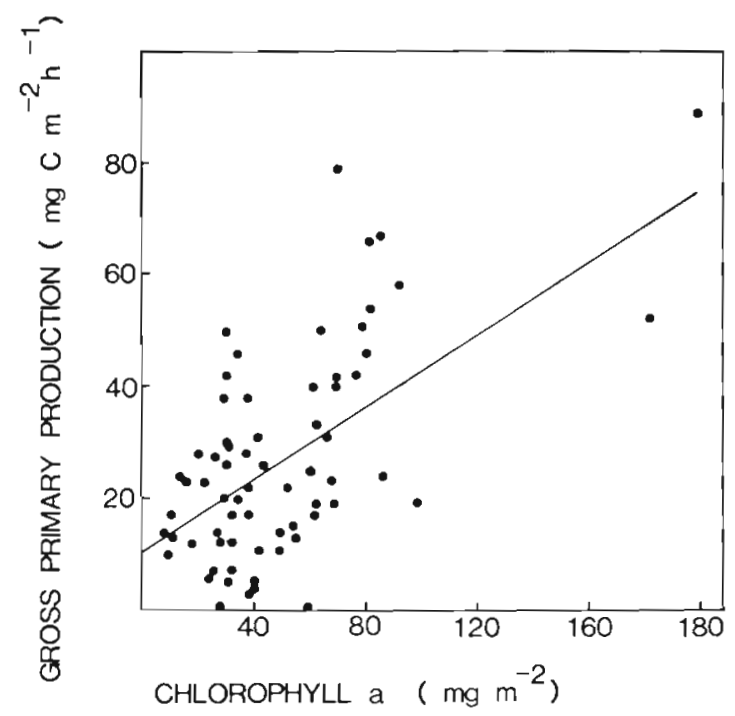

Fig. 5. Relationship of chlorophyll a concentration to gross primary production for pooled data from Netarts Bay. Fitted linear model: $\widehat{G P P}=9.57+0.35 \mathrm{CHLR}(\mathrm{n}=69), \mathrm{r}^{2}=0.40$

equations represent prediction of gross primary production for microalgal assemblages in the absence of sporelings and mature plants of Enteromorpha prolifera.

There was a significant correlation between gross primary production and community oxygen uptake $(r=0.42)$, as well as between temperature and community oxygen uptake $(r=0.45)$. No correlation was apparent between temperature and gross primary production however $(r=0.01)$.

\section{Effects of light intensity on primary production}

The relationship between light intensity and gross primary production of intact sediment cores collected from Yaquina Bay was investigated in March, April, August, and September 1980. Experiments were conducted outdoors under natural light. Representative experiments are shown in Fig. 6. These experiments

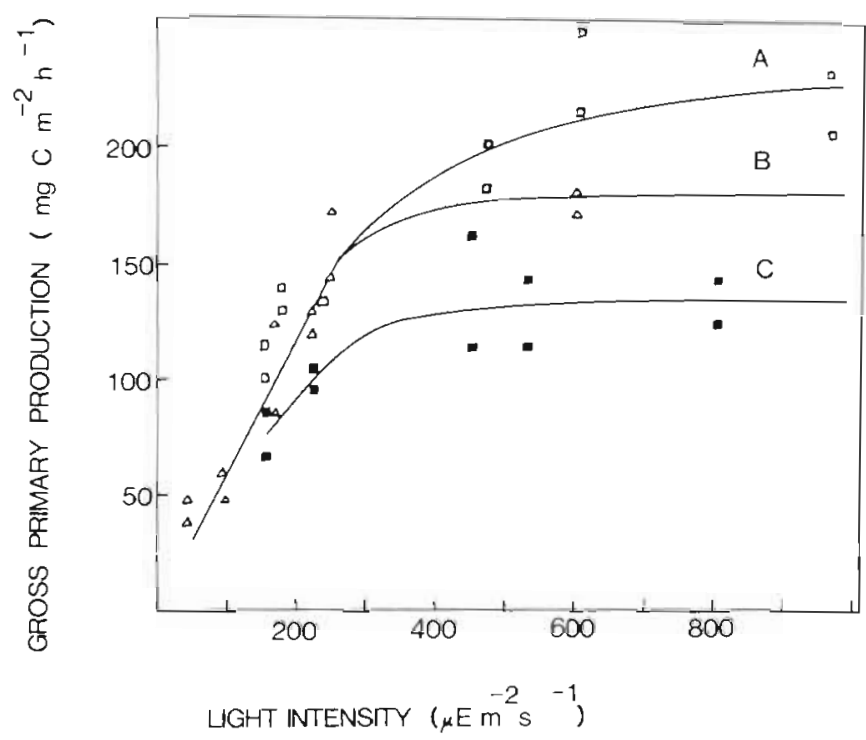

Fig. 6. Relationship of light intensity to gross primary production for intact sediment cores. Maximum gross primary production per unit chlorophyll a (mg Cmg chl $a^{-1} h^{-1}$ ) was $1.63,0.81$, and 0.64 , for experiments $\mathrm{A}, \mathrm{B}$, and $\mathrm{C}$, respectively. Temperature and salinity ranged from 12 to $14{ }^{\circ} \mathrm{C}$ and 30 to $33 \%$ S, respectively

represent similar variations in the ratio of gross primary production per hour per unit chlorophyll $a$ that were presented in Fig. 5. For experiments A, B, and C, the mean ratio at maximum photosynthetic rate was $1.63,0.81$, and 0.64 , respectively.

The relationship between light intensity and gross primary production was approximately linear from zero to $250 \mu \mathrm{E} \mathrm{m}^{-2} \mathrm{~s}^{-1}$, except in experiment $\mathrm{C}$ where the linear segment was between zero and $150 \mu \mathrm{E} \mathrm{m}^{-2} \mathrm{~s}^{-1}$ (Fig. 6). The equation for a linear segment from zero to $248 \mu \mathrm{E} \mathrm{m} \mathrm{m}^{-2} \mathrm{~s}^{-1}$ was estimated from data pooled for all 3 experiments: GPP $=0.59(\mathrm{I})$, where GPP is expressed as $\mathrm{mg} \mathrm{Cm} \mathrm{Cm}^{-2} \mathrm{~h}^{-1}$ and $\mathrm{I}$ is the light intensity. To estimate the asymptotic maximum rate $\left(P_{\max }\right)$ and the shape to the curves above $248 \mu \mathrm{E} \mathrm{m}^{-2} \mathrm{~s}^{-1}$. several functions that are commonly used to model photosynthesis-light relationship were examined (Lederman and Tett, 1981). The most satisfactory function was the exponential model:

$$
G P P=B_{0}-B_{1} e^{-B_{2} l}
$$


where $B_{0}$ is equal to $P_{\max }$. Curves generated by this equation for experiments $A, B$, and $C$ are illustrated in Fig. 6; corresponding estimates of $\mathrm{P}_{\max }$ are 233, 181 and $136 \mathrm{mg} \mathrm{C} \mathrm{m}^{-2} \mathrm{~h}^{-1}$, respectively.

Data in Fig. 6 indicate that the onset of light saturation of photosynthesis $\left(\mathrm{I}_{k}\right)$ occurs between 200 and $400 \mu \mathrm{E} \mathrm{m}^{-2} \mathrm{~s}^{-1}$. Here, $\mathrm{I}_{\mathrm{k}}$ is defined as the light intensity at which extrapolations of the linear segment and the light-saturated region of the GPP-light intensity curve intersect (Talling, 1957). Therefore, $I_{k}=P_{\max }$ ' 0.59 , where $P_{\max }$ is estimated by the exponential model and 0.59 , is the slope of the linear segment. From this expression, $I_{k}$ values for experiments $A, B^{\prime}$, and $C$ are 395,307 and $231 \mu \mathrm{E} \mathrm{m}^{-2} \mathrm{~s}^{-1}$, respectively.

\section{Effects of temperature on primary production and community oxygen uptake}

Effects of temperature on primary production and oxygen uptake in assemblages of sediment-associated microalgae were investigated in May 1981. Each experiment included 3 replications, i.e. three respirometers with intact sediment cores; and cores for each replication were collected from two intertidal levels in Yaquina Bay: $1.9 \mathrm{~m}$ and $1.0 \mathrm{~m}$ above MLLW. Water temperatures in Yaquina Bay during April and May varied between 11 and $14^{\circ} \mathrm{C}$. The temperature range under investigation was from 7 to $17^{\circ} \mathrm{C}$, a range between the maximum and minimum annual values recorded for Netarts Bay and Yaquina Bay. The light intensity during the primary production measurements was $600 \mu \mathrm{E} \mathrm{m}^{-2} \mathrm{~s}^{-1}$, an intensity well above the $I_{k}$ values determined during the experiments illustrated in Fig. 6. Results are reported as hourly rates and $\mathrm{Q}_{10}$ values were calculated where:

$$
Q_{10}=\left[r_{2} / r_{1}\right]^{10 /\left(t_{2}-t_{1}\right)}
$$

The temperature coefficient $\left(Q_{10}\right)$ is a multiplier that predicts the rate for a $10 \mathrm{C}^{\circ}$ change in temperature, $t_{2}$ and $t_{1}$ are the upper and lower temperatures of the range under consideration, and $I_{2}$ and $I_{1}$ are metabolic rates corresponding to $t_{2}$ and $t_{1}$, respectively.

Rates of gross primary production varied between 24.7 and $252.3 \mathrm{mg} \mathrm{C} \mathrm{m} \mathrm{C}^{-1}$, depending on temperature, experiment number, and replication. Therefore, estimates of $Q_{10}$ at light saturation were based on a set of samples representing a wide range of photosynthetic capacities. The mean $\mathrm{Q}_{10}$ value for three replications of each of 4 experiments $(n=12)$ was 2.05 with a standard error of 0.15 . There was no significant correlation between the mean rate of gross primary production for a particular experiment and its corresponding $Q_{10}$ value ( $r=-0.08$ with 10 d.f.). However, the mean $Q_{10}$ value was significantly higher for samples obtained at $1.9 \mathrm{~m}$ above MLLW than for samples taken at $1.0 \mathrm{~m}$ above MLLW $(t=22.27$ with $10 \mathrm{~d} . \mathrm{f})$; these mean values were 2.23 and 1.87 , respectively.

Temperature coefficients for rates of community oxygen uptake in the dark were more variable than values associated with changes in the rate of primary production. The mean $Q_{10}$ value for measurements of oxygen uptake $(\mathrm{n}=12)$ was 2.70 with a standard error of 0.39 . There was a significant negative correlation between the mean uptake rate for an experiment and the corresponding $Q_{10}$ values ( $r=-0.72$ with 10 d.f.). Also, the mean $Q_{10}$ value for samples from $1.9 \mathrm{~m}$ above MLLW was significantly higher than the mean for samples from $1.0 \mathrm{~m}$ above MLLW ( $\mathrm{t}=10.04$ with $10 \mathrm{~d}$.f.); these means were 3.32 and 2.08 , respectively.

\section{Some useful ratios}

The procedure for isolating living epipelic diatoms from sediment samples provided the opportunity to estimate some useful ratios for sediment-associated microalgal assemblages. The ratios of interest were: (1) biomass as ash-free dry weight to chlorophyll a (AFDW/CHLR); (2) gross primary production to chlorophyll a (GPP/CHLR); and (3) net primary production to gross primary production (NPP/GPP). The ratio AFDW/CHLR provided a basis for estimating autotrophic biomass in sediment-associated microal gal assemblages when such assemblages consisted primarily of diatoms, while NPP/GPP provided estimates of respiratory losses.

The mean value of AFDW/CHLR for 20 observations was 166.98 with a standard error of 8.20 ; this ratio ranged from 107.55 to 254.98. Estimates of GPP for the calculation of GPP/CHLR and NPP/GPP were based on the assumption that the rate of respiration in the dark was equal to the rate in the light. GPP/CHLR values for the diatom suspensions were considerably higher than values obtained at Netarts Bay and Yaquina Bay for intact sediment cores. The mean GPP/CHLR value for 28 observations was $5.12 \mathrm{mg} \mathrm{Ch}^{-1} \mathrm{mg}^{-1}$, and the associated standard error was $0.40 \mathrm{mg} \mathrm{C} \mathrm{h}^{-1} \mathrm{mg}^{-1}$. The mean NPP/GPP value for 27 observations was 0.71 with a standard error of 0.03 , indicating that respiration was approximately $29 \%$ of GPP for an equivalent period of time.

\section{Annual community primary production and oxygen uptake}

Annual rates of community primary production and oxygen uptake were calculated assuming the following information. Daily rates, which were calculated as 
Table 2. Calculated estimates of annual sediment-associated mean microalgal biomass and total primary production in Netarts Bay at the SAND, FINE SAND, and SILT sites. Tidal levels are $0.5 \mathrm{~m}, 1.0 \mathrm{~m}$, and $1.5 \mathrm{~m}$ above MLLW. Variables, expressed as g C m${ }^{-2}$, include: mean microalgal biomass (Biomass), gross primary production (GPP), microalgal respiration (RESP), net primary production (NPP), community oxygen uptake (OUPTK), and non-algal community oxygen uptake (Non-algal OUPTK). Non-algal OUPTK equals OUPTK - RESP

\begin{tabular}{|c|c|c|c|c|c|c|}
\hline Site & Biomass & GPP & RESP & NPP & OUPTK & $\begin{array}{c}\text { Non-algal } \\
\text { OUPTK }\end{array}$ \\
\hline \multicolumn{7}{|l|}{ SAND } \\
\hline $0.5 \mathrm{~m}$ & 6.22 & 107.5 & 73.1 & 34.4 & 109.6 & 36.5 \\
\hline $1.0 \mathrm{~m}$ & 6.34 & 204.5 & 139.9 & 64.6 & 140.0 & 23.1 \\
\hline $1.5 \mathrm{~m}$ & 1.94 & 74.9 & 59.2 & 15.7 & 50.0 & 13.3 \\
\hline \multicolumn{7}{|c|}{ FINE SAND } \\
\hline $0.5 \mathrm{~m}$ & 5.21 & 151.3 & 99.6 & 51.8 & 116.2 & 44.6 \\
\hline $1.0 \mathrm{~m}$ & 4.31 & 145.7 & 97.3 & 48.5 & 248.1 & 150.9 \\
\hline $1.5 \mathrm{~m}$ & 5.09 & 162.6 & 102.8 & 59.8 & 225.1 & 122.2 \\
\hline \multicolumn{7}{|l|}{ SILT } \\
\hline $0.5 \mathrm{~m}$ & 3.94 & 64.0 & 49.5 & 14.5 & 130.5 & 81.0 \\
\hline $1.0 \mathrm{~m}$ & 6.09 & 63.7 & 45.7 & 18.1 & 162.8 & 117.2 \\
\hline $1.5 \mathrm{~m}$ & 5.00 & 87.9 & 56.3 & 31.7 & 174.6 & 118.4 \\
\hline
\end{tabular}

an index of benthic autotrophy (see above), were extrapolated to monthly rates by multiplying by 30 . Monthly production was then summed for the year. The hourly rate of algal respiration was assumed to be $29 \%$ of the hourly rate of gross primary production. Microalgal biomass was calculated by multiplying chlorophyll a concentration by 83.49 , assuming that one half the microalgal organic matter concentration was carbon, and chlorophyll a concentration $\times 166.98=$ microalgal organic matter concentration (see above). The results of these calculations are given in Table 2. Estimates were made only for levels at $0.5 \mathrm{~m}, 1.0 \mathrm{~m}$, and $1.5 \mathrm{~m}$ above MLLW at the SAND, FINE SAND, and SILT sites. The FINE SAND site generally had the highest primary production and community oxygen uptake.

\section{DISCUSSION}

This investigation was designed to test the hypotheses that sediment type, tidal height and season were significant factors in determining the production dynamics of sediment-associated algae in estuaries. To test these hypotheses we chose an estuary where gradients of sediment type and tidal height were separated from each other. In previous studies, results showed that sediment grain size generally decreased with increasing tidal height and was presumed to be related to the frequency of disturbance associated with wave action and scouring (Cadée and Hegeman, 1977; Colijn and Dijkema, 1981). Our results indicated that the SAND, FINE SAND, and SILT sites were distinct sites relative to grain size distributions (Davis, 1981).
Therefore we could expect to separate the effects of tidal height from sediment type. The fact that much of the intertidal area of Netarts Bay was covered with a film of water during exposure tended to decrease the effects of drying and large fluctuations of temperature and salinity, creating a more moderate habitat for algal growth than was described for a sand flat in the Danish Wadden Sea by Rasmussen et al. (1983).

The pattern of temporal variation of chlorophyll a concentration was similar to that observed by Colijn and Dijkema (1981), with seasonal maxima evident in the spring and fall. Although Colijn and Dijkema (1981) were unable to ascribe a mechanism for the apparent summer depression of chlorophyll $a$, recent experiments with intact sediment cores have demonstrated that infauna have a significant effect on microalgal abundance and production which could account for this summer decrease (Davis and Lee, 1963).

Spatial patterns of chlorophyll a were associated with sediment type and tidal height. In this study, chlorophyll a concentration was higher in silty sediment relative to sandy sediment, although this pattern was confined to $1.5 \mathrm{~m}$ and $2.0 \mathrm{~m}$ above MLLW, except at the SAND site where there was less chlorophyll a at these elevations. This complicated pattern was associated with the apparent reduction of animal abundance at the higher tidal heights at the FINE SAND and SILT sites, while at the SAND site, a large bed of Callianassa was present above $1.4 \mathrm{~m}$ above MLLW. Other studies have reported that chlorophyll a concentration simply increased with increasing silt content (Cadée and Hegeman, 1977; Coles, 1979; Colijn and Dijkema, 1981). Microalgal biomass was also affected by interaction with Enteromorpha prolifera and Zostera 
marina. At times, both of these macrophytes shaded sediment and competed for space, while trapping large amounts of sediment locally, as was observed by Frostick and McCave (1979). In other estuaries, chlorophyll a concentration was inversely related to wave action, water currents and storm activity (Pamatmat, 1968; Colijn and Dijkema, 1981). The effects of these factors were apparent in Netarts Bay, but were limited to local areas where tidal scour was obvious, creating unstable substrate conditions associated with tidal drainage channels.

The concentration of organic matter was maximum during the summer, associated with the influx of Enteromorpha and Zostera. This material was distributed throughout the estuary by tidal transport and deposition, especially at the stand line at $2.0 \mathrm{~m}$ above MLLW at the FINE SAND and SILT sites. The spatial patterns of organic matter were similar to those of chlorophyll $a$, as discussed above. These spatial patterns were associated with the depositional conditions present at the sites. Similar patterns have been demonstrated in other estuaries (Cadée and Hegeman, 1977; Edwards, 1978).

Maximum calculated hourly rates of gross primary production occurred during the summer at all 3 study sites. Increasing temperature probably enhanced the production rates during summer, as shown by laboratory experiments with intact cores. The results of these experiments were very similar to results of previous research reported by Colijn and van Buurt (1975). Although large plants of Enteromorpha prolifera were excluded from the microalgal production measurements, sporelings were present in the sediment at the SAND and FINE SAND sites and presumably could contribute significantly to benthic primary production during the summer. There were no significant differences in hourly rates of gross primary production associated with sediment type or tidal height, although the SILT site had generally lower production throughout the year, at all tidal heights. This depression was associated with the lack of $E$. prolifera sporelings and the decreased light levels associated with silty sediment. The lack of effect of tidal height on gross primary production may indicate that light was generally not limiting to photosynthesis at these sites. Cadée and Hegeman (1977) found a correlation between tidal height and primary production, suggesting light limitation of photosynthesis associated with the effects of tidal inundation.

Maximum community oxygen uptake occurred in the summer, associated with increased temperature and organic matter concentrations. A similar pattern was found by Duff and Teal (1965), Pamatmat (1968) and Davies (1975). The laboratory experiments with intact cores also showed increased community oxygen uptake associated with increased temperature. Apparently community oxygen uptake was not limited by substrate concentration, as mean organic matter concentration was highest at the SILT site, while mean community oxygen uptake was highest at the FINE SAND site. Other studies have indicated that oxygen uptake may be correlated with organic matter concentration (Pamatmat, 1975; Edwards, 1978). Much of the organic matter at the SILT site was probably refractory (e.g. twigs and leaves) and derived from terrestrial sources. This material was probably relatively unavailable for rapid processing through detrital food webs (Johnson, 1977).

Although chlorophyll a concentration may be a significant predictor of gross primary production, there are problems with this apparent relationship with respect to sediment-associated algae. The relationship can be affected by variations in the chlorophyll a to biomass ratios (Jonge, 1980), by variations in photosynthetic efficiency of chlorophyll a associated with the growth and senescence of benthic algae, and by analytical errors associated with the measurement of chlorophyll $a$ in sediment (Whitney and Darley, 1979) and sediment-associated primary production. Future research should investigate the dynamic fluctuations of the relationship between chlorophyll a and gross primary production associated with the effects of these factors. Although fluctuations in photosynthetic efficiency exist, they do not appear to influence the relationship between light intensity and gross primary production determined in the laboratory, except possibly to increase the apparent saturation intensity. The results of these laboratory experiments were similar to other studies with isolated benthic diatoms (Admiraal, 1977; Rasmussen et al., 1983). Although light saturation of photosynthesis was greater than $200 \mu \mathrm{E} \mathrm{m}^{-2} \mathrm{~s}^{-1}$, saturation of growth is expected to be at a lower light intensity $\left[\left(70 \mu \mathrm{E} \mathrm{m}^{-2} \mathrm{~s}^{-1}\right)\right.$, as found by Admiraal (1977)] for benthic diatoms in culture.

Calculated estimates of annual sediment-associated production were similar to values reported previously for estuarine production (Pamatmat, 1968; Cadée and Hegeman, 1977) and indicated several patterns relative to the hypotheses that production dynamics were controlled by sediment type and tidal height. These patterns did not fit with the results of previous research which showed that algal biomass and production were negatively related to grain size and that tidal height influenced production by creating light limiting conditions for growth (Cadée and Hegeman, 1977; Colijn and Dijkema, 1981). Although there were obvious effects of season, sediment type, and tidal height on the production dynamics of benthic algae, these relationships were not linear and suggested that other factors also were controlling the observed patterns. 
Possible mechanisms include the effects of infauna (Davis and Lee, 1983) and epifauna (Pace et al., 1979), possible lack of light limitation associated with tidal inundation, and heterotrophic nutrition of benthic algae which would modify the effects of physical factors on photosynthesis (Admiraal and Peletier, 1979; McLean et al., 1981). Inorganic nutrient concentrations are not expected to have a significant effect on benthic algal dynamics because of the abundance of nutrients associated with sediments (Welsh, 1980; Cardon, 1981).

In conclusion, the hypotheses that production dynamics of benthic algae could be explained by changes associated with tidal height and sediment type were not substantiated in a manner consistent with previous published research. Variations associated with season were consistent with previous research. Future research on sediment-associated algal production dynamics should concentrate on chemical and biotic factors which can potentially modify patterns of production (e.g. Davis and Lee, 1983; Rasmussen et al., 1983). Variation in physiological condition of the algae is also expected to contribute to the patterns observed in the field and should be investigated in more detail (Admiraal and Peletier, 1980).

Acknowledgements. We are indebted to Dr. Harold V. Kibby, Corvallis Environmental Protection Agency Research Laboratory, for serving as our EPA Project Officer, and for providing relevant data from an earlier study at Netarts Bay. Thanks also to Nanette Cardon for help in the field and the laboratory and to Mary Kentula for help in designing the large chamber.

This research was supported by a grant from the United States Environmental Protection Agency, No. R806780 to C. David McIntire. Partial support during preparation of this manuscript was given to $\mathrm{M}$. W. Davis by a Postdoctoral Fellowship from Harbor Branch Institution. Harbor Branch Foundation Contribution No. 342

\section{LITERATURE CITED}

Admiraal, W. (1977). Influence of light and temperature on the growth rate of estuarine benthic diatoms in culture. Mar. Biol. 39: 1-9

Admirad, W., Peletier, H. (1979). Influence of organic compounds and light limitation on the growth rate of estuarine benthic diatoms. Br. phycol. J. 14: 197-206

Admiraal, W., Peletier, H. (1980). Influence of seasonal variation of temperature and light on the growth rate of cultures and natural populations of intertidal diatoms. Mar. Ecol. Prog. Ser. 12: 35-43

Amspoker, M. C., McIntire, C. D. (1978). Distribution of intertidal diatoms associated with sediments in Yaquina Estuary, Oregon. J. Phycol. 14: 387-395

Buchanan, J. B., Kain, J. M. (1971). Measurements of the physical and chemical environment. In: Holmes, N. A., McIntyre, A. D. (ed.) Methods for the study of marine benthos. IBP Handbook No. 16. Blackwell, Oxford, p. $30-56$

Cadée, G. C., Hegeman, J. (1974). Primary production of the benthic microflora living on tidal flats in the Dutch Wadden Sea. Neth. J. Sea Res. 8: 260-291

Cadée, G. C., Hegeman, J. (1977). Distribution of primary production of the benthic microflora and accumulation of organic matter on a tidal flat area, Balgzand, Dutch Wadden Sea. Neth. J. Sea Res. 11: 24-41

Cardon, N. C. (1981). The effect of nutrient entrichment on benthic diatoms of Yaquina Bay, Oregon. M. Sc. thesis, Oregon State University, Corvallis

Coles, S. M. (1979). Benthic microalgal populations on intertidal sediments and their role as precursors to salt marsh development. In: Jefferies, R. L., Davy, A. J. (ed.) Ecological processes in coastal environments. Blackwell, Oxford, p. $25-42$

Colijn, F., Buurt, G., van (1975). Influence of light and temperature on the photosynthetic rate of marine benthic diatoms. Mar. Biol. 31: 209-214

Colijn, F., Dijkema, K. A. (1981). Species composition of benthic diatoms and distribution of chlorophyll $a$ on an intertidal flat in the Dutch Wadden Sea. Mar. Ecol. Prog. Ser. 4: 9-21

Davies, J. M. (1975). Energy flow through the benthos in a Scottish sea loch. Mar. Biol. 31: 353-362

Davis, M. W. (1981). Production dynamics of sediment-associated algae in two Oregon estuaries. Ph. D. thesis, Oregon State University, Corvallis

Davis, M. W., Lee, H. (1983). Recolonization of sedimentassociated microalgae and effects of estuarine infauna on microalgal production. Mar. Ecol. Prog. Ser 11: 227-232

Duff, S., Teal, J. M. (1965). Temperature change and gas exchange in Nova Scotia and Georgia salt marsh muds. Limnol. Oceanogr 10:67-73

Edwards, R. R. C. (1978). Ecology of a coastal lagoon complex in Mexico. Estuar. coast. mar. Sci. 6: 75-92

Frostick, L. E., McCave, I. N. (1979). Seasonal shifts of sediment within an estuary mediated by algal growth. Estuar. coast. mar. Sci. 9: 569-576

Haardt, J., Nielsen, G. (1980). Attenuation measurements of monochromatic light in marine sediments. Oceanologica Acta 3: $333-338$

Johnson, R. G. (1977). Vertical variation in particulate matter in the upper twenty centimeters of marine sediments. J. mar. Res. 35: 273-282

Jonge, $\mathrm{V}$ N., de (1980). Fluctuation in the organic carbon to chlorophyll a ratios for estuarine benthic diatom populations. Mar. Ecol. Prog. Ser. 2: 345-353

Kjeldsen, C. K., Phinney, H. K. (1971). Effects of variations in salinity and temperature on some estuarine macroalgae. In: K. Nisizawa (ed.) Proceedings of the seventh international seaweed symposium. John Wiley and Sons, New York, p. 301-308

Lederman, T. C., Tett, P. (1981). Problems in modelling the photosynthesis-light relationship for phytoplankton. Botanica mar. 24: 125-134

McIntire, C. D., Wulff, B. L. (1969). A laboratory method for the study of marine benthic diatoms. Limnol. Oceanogr. 14: $667-678$

McLean, R. O., Corrigan, J., Webster, J. (1981). Heterotrophic nutrition in Melosira nummuloides, a possible role in affecting distribution in the Clyde estuary. Br. phycol. J. 16: $95-106$

Nie, N. H., Hill, C. H., Jenkins, J. S., Steinbrenner, K., Bent, D. H. (1975). SPSS: statistical package for the social sciences, 2nd. ed. McGraw-Hill, Inc., New York 
Pamatmat, M. M. (1968). Ecology and metabolism of a benthic community on an intertidal sandflat. Int. Revue ges. Hydrobiol. 53: 211-298

Pamatmat, M. M. (1975). In situ metabolism of benthic communities. Cah. Biol, mar. 16: 613-633

Rasmussen, M. B., Henriksen, K., Jensen, A. (1983). Possible causes of temporal fluctuations in primary production of the microphytobenthos in the Danish Wadden Sea. Mar. Biol. 73: 109-114

Riznyk, R. Z., Phinney, H. K. (1972). Manometric assessment of interstitial microalgal production in two estuarine sediments. Oecologia (Berl.) 10: 193-203

Rowe, K., Brenne, R. (1981). Statistical interaction programming system (SIPS). Statistical Computing Report No. 7. Oregon State University, Corvallis

Ryther, J. H. (1956). The measurement of primary production. Limnol. Oceanogr. 1: 72-84

Strickland, J. D. H., Parsons, T. R. (1972). A practical handbook of seawater analysis. 2nd ed. Bull. Fish. Res. Bd Can. 167: $1-310$
Talling, J. F. (1957). Photosynthetic characteristics of some freshwater diatoms in relation to underwater radiation. New Phytol. 56: 29-50

U. S. Environmental Protection Agency (1978). Unpublished data, wetlands research program, Corvallis, Oregon

Welsh, B. L. (1980). Comparative nutrient dynamics of a marsh-mudflat ecosystem. Estuar. coast. mar. Sci. 10: 143-164

Westlake, D. F. (1965). Some basic data for investigations on the productivity of aquatic macrophytes. Memorie Ist. ital. Idrobiol. 18: 229-248

Whitney, D. E., Darley, W. M. (1979). A method for the determination of chlorophyll $a$ in samples containing degradation products. Limnol. Oceanogr. 24: 183-186

Wulff, B. L., Mclntire, C. D. (1972). Laboratory studies of assemblages of attached estuarine diatoms. Limnol. Oceanogr. 17: 200-214

This paper was presented by Professor S. W. Nixon; it was accepted for printing on July 6, 1983 